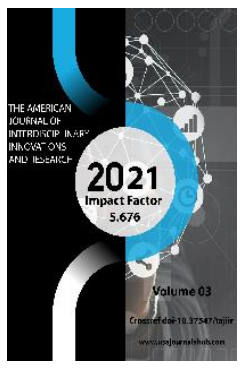

Copyright: Original content from this work may be used under the terms of the creative commons attributes 4.0 licence.

\section{Genesis And Evolution Of Propaganda And Agitation}

\author{
Mansur Tuychiyevich Vakhabov \\ Senior Teacher, Department Of Humanities, Culture And Physical Education, Institute Of \\ Veterinary Medicine, Samarkand, Uzbekistan \\ Latif Uroqovich Jamolov \\ PhD, Department Of Humanities, Culture And Physical Education Institute Of Veterinary \\ Medicine, Samarkand, Uzbekistan
}

Akbar Suvanovich Daminov

Teacher, Department Of Humanities, Culture And Physical Education Institute Of Veterinary Medicine, Samarkand, Uzbekistan

\title{
ABSTRACT
}

One of the most important issues in the study of the phenomenon of propaganda and agitation in social philosophy, the laws and principles of their application in the spiritual sphere, is the question of the emergence and development of propaganda and agitation. This article aims to study the genesis and evolution of these phenomena by analyzing the types, methods and means of propaganda and propaganda from antiquity to the Middle Ages on the basis of the logical-historical method, while describing some socio-philosophical issues of propaganda today.

\section{KEYWORDS}

Propaganda, agitation, globalization, ontology, genesis, spirituality, idea, ideology, preaching, writing, preaching, sultanate, discussion, peace of country, creative ideas, social feelings, habits, social consciousness, propaganda, agitation, positive, negative , a bipolar world.

\section{INTRODUCTION}

During the years of independence, exemplary work has been done in our country to strengthen the spiritual and enlightenment foundations of society [2]. 
But today, the processes of globalization are intensifying in the world, and new threats and dangers to peace and stability are growing. Such a complex and dangerous situation requires a critical assessment of the work done in the field and the improvement of our activities in this area in accordance with modern requirements [2].

So, improving the field of propaganda and advocacy is a requirement of the time for a scientific approach to this issue. It is this issue that makes the issues of propaganda and advocacy the object of scientific research.

We will try to study the genesis and evolution of these phenomena by analyzing the types, methods and means of propaganda and propaganda that existed from ancient times to the Middle Ages on the basis of the logicalhistorical method. In this context, we consider some of the socio-philosophical issues of today's propaganda and advocacy.

\section{THE MAIN PART}

Propaganda and propaganda is an exaggeration to say that it is "as old as humanity itself." However, it is difficult to object to the idea that their emergence and formation dates back to ancient times. Since the beginning of the conscious, philosophical activity of mankind and the expression of its dreams, goals and interests in ideas, there are still two main ways to convey these ideas, the teachings that emerged as their system: the first: through education, teaching, teaching, the second is by promoting their own ideas and views and, consequently, their goals and aspirations.
It should be noted that the unique role of the education system in the socialization of the individual was instinctively felt in ancient times. formed.

At the beginning of the tribal period, wrist strength, vigor, and, perhaps, ruthlessness may have been enough to take over the management of the community. But as the tribes merged and the tribes emerged, as they grew older, the ability to follow the masses, to have speech and logic, to captivate people with the magic of words, began to play a key role. In addition, it is the same kind of propaganda and propaganda that promotes ideas that can express the vital goals and interests of the tribe, encourages the conquest of neighboring peoples and nations, and seeks to justify the tribal cause of death. considered to be

Although the term "propaganda" originated in the Catholic Church in the early 17th century, propaganda as a social phenomenon has existed since time immemorial. Some experts cite the preamble of the Hammurappi Code of Laws as one of the earliest forms of propaganda. It is known that the preamble states that these laws were created to establish justice in the country, to protect the weak from the strong. However, the laws, by their very nature, protected the interests of the nobility and the upper classes, while the oppressed remained unjust and disenfranchised.

Russian expert Vladimir Krisko's book "Secrets of Psychological Warfare" provides information on the widespread use of ideological, spiritual and ideological means of influence in ancient times and the Middle Ages. In particular, e. a. The ancient Chinese 
philosopher and military man of the sixth century, Sun Tzu, before the conquest of other lands, turned all the good in the rival country into evil, sow discord among citizens and peoples, incite the youth to the old, intensify protests, devalue all traditions and beliefs. "[5].

Sun Tzu's "advice" to his ruler was as follows: 1) take measures to destroy everything that is good in your opponent's country; 2) drag prominent figures of the enemy side into the whirlpool of criminal behavior; 3) discredit the leaders of the enemy, take the path of embarrassment in public; 4) for these purposes, collude with the most vile and strange elements on the opponent's side; 5) incite discord among the citizens of the enemy; 6) turn young people against the elderly; 7) obstruct the work of the government as much as you can; 8) loosen the discipline in the army of the enemy, impede the normal supply of servicemen; 9) exaggerate the melodies to loosen the will of the warriors of the opposing side; 10$)$ do whatever is necessary to discredit the good traditions of your enemies, to undermine their faith in their religion; 11) send liquid-footed women, prostitutes to the opponent's side to perfect the work of vandalism; 12) to turn to your side and give gifts to get the necessary information, do not spare money when filling the sheep with empty nuts; 13) In general, the more false promises you make in the way of your goal, the more money you spend, the better the result [5].

It is clear that in this case, not spiritual, but selfish propaganda is being encouraged, and goodness, not goodness, but evil and depravity are being promoted. But whatever the essence and content, the form places a great deal of emphasis on propaganda and advocacy.
In Central Asia, especially in the territory of modern Uzbekistan, propaganda and agitation, the culture of speech and the art of oratory, which are their means, did not appear spontaneously. They have deep historical roots and ideological sources, and in ancient times the art of preaching was given great attention, and many of its talented representatives set an example and left a rich legacy.

The word "sermon" in Arabic means preaching, exhortation; The word "preacher" means a person who preaches. The art of preaching is the art of influencing the mind and emotions of the listener, the community, and is now referred to as the art of oratory.

In the ancient East (until the ninth century) kings and caliphs preached. They gathered the community on Fridays, Eid, and other holidays to preach on public policy, the duties and responsibilities of citizens (including obedience, obedience to the law), the situation in other countries, the intrigues of enemies, defense issues, and more.

From the ninth century onwards, the rulers of the state entrusted this event to the masters of special words at their disposal, and began to call them preachers. The word "preacher" was even added to their names.

The treasures of the Central Asian art of preaching were first made by such masters of speech as Bahovuddin Valad (XII century), Jalaliddin Rumi (XIII century), Hussein Kashifi, Muin preacher (XV century).

Since the twelfth century, many scientific, historical, methodological treatises have been written that interpret and describe the theory and practice of the art of preaching. These 
include Muhammad Rafiq Wa'iz's Avbab ulJinan, Waz Qazvini's Zilolu Makal, Waz Shirvani's Ahsan ul-Ahadith, Muhammad Waz's Hidayat ul-Taqwim, Quraysh Sa'idi's Anis ulWaizin, Wazir Samarkandi's Ravazat. ul-voizin ", Qazi Oshi's« Miftoh ul-najjih », Waz Kashifi's« Dah majlis », "Mahzan ul-insho ». The works of historians, poets, and hadith scholars also contain some ideas related to the art of preaching. For example, in the historian Ali Yazdi's "Zafarnoma", in Navoi's "Majlis unnafois", "Mantiq ut-tayr", "Mahbub ul-qulub", "Hamsa", "Chor devon"; Zaynuddin Wasifi's (15th century) treatise Badoe ul-Waqoe and Khandamir's Makorim ul-Akhlaq discuss the skills, talents, and methods of preaching of famous preachers. Mawlana Navoi noted that the preachers delivered their speeches in the form of "crazy on the pulpit" and with fiery warmth and emotion.

According to historians, such statesmen as Amir Temur, Mirzo Ulugbek, Hussein Boykaro, Babur Mirzo mastered the art of preaching and used it skillfully in their work.

Mawlana Irshad, Oshiy, Mehnagiy, Riyazi, Kashifi, Muin and others were the leaders of the propaganda art of the 15th century. The art of preaching has bequeathed to us the pages of the history of the spirituality of the peoples of Central Asia, especially the Uzbek nation, which are worth writing in golden letters.

The bottom line is that most of the preachers of the Uzbek people's past have been very demanding of themselves, and have spoken to a small audience. They felt a great responsibility to their riders; they did not come to the people without extensive and deep knowledge and mastery of exemplary skills.
This quality is an invaluable legacy for modern propagandists, and if its successors learn from their predecessors, they will never go astray. Indeed, there is an integral unity, the inheritance, between the art of preaching in the East and the propaganda culture of the present. Today's propagandists, professors, teachers, poets and writers should be worthy heirs of the spiritual heritage left to us by our forefathers.

It is clear from the above that propaganda and agitation have evolved in harmony with humanity since ancient times, manifested in various forms. But not a breath took it.

Today, a number of studies are being conducted in world scientific centers to study propaganda, its forms and means, its power and effectiveness. In particular, in addition to the existing political propaganda, there were sociological propaganda, vertical and horizontal, rational-irrational propaganda. But in many cases, centers that want to promote and propagate their ideas and values do so in a very masked way. Terrorist groups, missionary organizations, and the American way of life are examples of this. It is no coincidence that some experts describe the current process not as "globalization" but as "Americanization" [9].

In these dangerous times, the struggle for the human mind and heart is intensifying all over the world. In particular, the attempt to capture the consciousness of the younger generation, to subjugate it spiritually and spiritually, is becoming very dangerous. The President of Uzbekistan Shavkat Mirziyoyev warned the international community from the UN rostrum. 
One of the important features of the era of globalization is the emergence of a global information space, the formation of a planetary-scale communication system through the Internet and mobile communications. Under such conditions, the human mind and consciousness begin to be invaded by the flow of information in all directions and in all directions. There is no doubt that any owner of information and data is interested in disseminating their message, and thus their thoughts and ideas. There is no mechanism for this other than propaganda and agitation. Once upon a time, people themselves understood our ideas and goals, so the subjects who waited for time to follow us could not turn anyone to their side, could not play a role in the life scene. Only those forces in the political arena that are able to disseminate their ideas in a way that is understandable and convincing to the public will achieve their goals. [7]

In a 2009 interview with Euronews a few days before his election as President of the European Parliament, Eji Buzek commented on popular forms of propaganda: "I think we need to focus on the issues that are closest to our citizens, because people need bread. and need oil, they are interested in what is needed in their daily lives. That is why lofty rumors about a crisis or energy shortage do not reach their ears. When it comes to energy security, we need to explain to people that the gas stove in your home is always on without turning off, and there is always electricity in the electrical outlet. What we do is nothing more than that. When we bring new technologies, when we buy new things, when we build infrastructure, all of this is always on the roof. We need to make sure that the electricity in your hotel does not go out. To do this, we need to translate it into simple language, because the person driving the car understands that he needs a source of energy, gasoline. We sometimes throw our words at the stratosphere, even though our words have to be grounded. "[7]

All of the above reflects the specificity of the ideological world today and, in turn, globalizes the issue of ideological inviolability of our people, increasing their resilience to various threats. We must first ensure the psychological security of young people. Psychological security in scientific sources refers to the state of readiness of people not to succumb to attacks based on various information, mentally, voluntarily, or a related process. We adults, enlighteners and professionals need to know, of course, what qualities and spiritual experiences this condition is associated with in a person.

When analyzed psychologically, the state of security in an individual is explained through a number of concepts: nonconformism is a condition in which an individual or group is not subject to the influence of another person or social group, indicating that there is a strong resistance to it. Some experts also describe nonconformism as "the presence of ideological immunity". It is a reflection of the phenomenon of conciliation, that is, conformism, which explains the influence of a group in real or imaginary on a person's beliefs and behavior. It can take two forms:

- Concession - following the opinion of the majority in external action, even if the heart does not agree; 
- Approval - the full conformity of beliefs and views to social pressure.

The question of whether giving or approving does not undermine an individual's identity and independence is appropriate. The answer comes from two sources - the system of norms that society has developed for people, the desire to be recognized by others, and the exchange of words and phrases. -try to explain through their effects on each other.

Thus, independent thinking is the ability of an individual to react directly to himself, to react to the various influences of the external environment through his thoughts, and to resist it if necessary.

The lack of independent thinking is, unfortunately, common among some categories, especially young people who are not involved in the higher and secondary special education system, among women. In this case, the risk of people falling under the influence of destructive ideas, the whirlpool of foreign ideologies increases. The ability of a person to resist with thought against thought, with idea against idea, with enlightenment against ignorance, narrows. This is arguably one of the biggest problems in educating young people ideologically.

In fact, it is we, the adults, the coaches, who in many cases teach children - from infancy, youth - from adolescence to just imitate, not to deviate from what is said. We do not know that this analysis has made them unwilling, indecisive, insecure. Depending on the actions of such young people, they are sometimes reprimanded and punished for their helplessness and unwillingness due to lack of independent thinking.

It should be noted once again that independent thinking is a person's inner ability, mental readiness to identify, analyze and distinguish the essence of events that occur in everyday life, their secrets. Only such a psychological state encourages a person to think, to observe, to think.

At this point, it may be appropriate to recall the opinion of Walter Lippmann. As this famous psychologist put it, "Where everyone thinks the same, no one thinks much."

So, in essence, we are a product of our own culture and the social being that surrounds us, we are dependent on situations, and we are obsessed with the influences that others have on us. It is known that the indulgence of some young people in ignorance and religious fanaticism, their unknowingly joining various destructive ideas and calls, and their involvement in the abominable acts of terrorism and many other crimes have led to such a situation. Therefore, the main task is to educate everyone to be able to put their personal worldview and beliefs, healthy views against this or that threatening and dangerous or conflict situations.

So, personal opinion is of great importance. People behave differently in different social situations, in fact, they think differently, the art of thinking, reasoning, cold thinking is a pedagogical tool that we adults can use in the education of national ideology. So, positive thinking, positive thinking - leads to good results, positive results. If we tell our children, "Be a free citizen of your country! Be the 
master of your own destiny! You deserve it! " that is to say, both his thoughts and his behavior fall into this state.

\section{CONCLUSION}

The Constitution of the Republic of Uzbekistan guarantees freedom of propaganda and agitation, ie propaganda and agitation. Article 29 of the Basic Law states that "Everyone has the right to freedom of thought, speech and religion. Everyone has the right to seek, receive and impart information of his choice, with the exception of information directed against the existing constitutional order and other restrictions established by law. "[1]

In order for citizens to fully enjoy these rights, it is necessary to regulate the relationship between them and the state. The development of a clear mechanism for this task, the use of new, modern technologies of information transmission will become one of the most pressing issues today.

\section{REFERENCES}

1. The Constitution of the Republic of Uzbekistan.-T., Uzbekistan, 2001.B.11.

2. Resolution of the President of the Republic of Uzbekistan "On increasing the effectiveness of spiritual and educational work and raising the development of the industry to a new level." Tashkent, July 28 , 2017.

3. Mirziyoev Sh.M. Speech at the 72nd Session of the United Nations General Assembly. New York. September 19, 2017. // Toshkent. "Uzbekistan". 2017.
4. Address of the President of the Republic of Uzbekistan Shavkat Mirziyoyev to the Oliy Majlis. January 24, 2020. // "People's speech", January 25, 2020.

5. Krysko V. Secrets of psychological warfare. M. 1997.

6. Qiyomiddin Nazarov. Current issues of spirituality. - Tashkent, "Muharrir" publishing house, 2010; ...

7. Ochildiev A. Globalization and ideological processes. - Tashkent, “Editor”, 2009.

8. Koleman Dj. Committee 300. - Moscow, 2008.

9. Volker Berghahn Globalization, Americanization, Europeanization - III. Globalist.2008. №4. S.13.

10. Farfieva, K. A. (2021). Theoretical Fundamentals Of Scientific And Innovative Thinking In Adolescents. The American Journal of Social Science and Education Innovations, 3(04), 431-437. 